\title{
Permeability characteristics of the epithelium in the rat caput epididymidis
}

\author{
B. T. Hinton and S. S. Howards \\ Departments of Urology and Physiology, University of Virginia School of Medicine, \\ Charlottesville, Virginia 22908, U.S.A.
}

\begin{abstract}
Summary. Micropuncture techniques were used to study the in-vivo transfer of radioactive compounds of different molecular weights across the epithelium of the rat caput epididymidis. Small molecular weight compounds such as ${ }^{3} \mathrm{H}_{2} \mathrm{O}$ and $\left[{ }^{14} \mathrm{C}\right]$ rea equilibrated in less than $20 \mathrm{~min}$ and $2 \mathrm{~h}$ respectively after intravenous injection. Compounds of larger molecular weight $\left(\left[{ }^{3} \mathrm{H}\right]\right.$ polyethylene glycol, $\left[{ }^{3} \mathrm{H}\right]$ inulin and ${ }^{125}$ I-labelled bovine serum albumin) entered the lumen more slowly and reached less than $5 \%$ of blood plasma concentrations $3 \mathrm{~h}$ after injection. The luminal concentration of $\left[{ }^{3} \mathrm{H}\right]$ inulin remained below $7 \%$ of the blood level for $18 \mathrm{~h}$. These results demonstrate that a permeability barrier exists in the epithelium of the rat caput epididymidis.
\end{abstract}

\section{Introduction}

Developing spermatozoa in the seminiferous tubules are protected by a specialized barrier. In several species, the anatomical (Dym \& Fawcett, 1970; Fawcett, Leak \& Heidger, 1970) and physiological (see Setchell \& Waites, 1975; Setchell, 1980) roles of the blood-testis barrier are well documented. However, very few data are available for the blood-epididymis barrier. Howards, Jessee \& Johnson (1976) examined the transfer of substances of different molecular weight across the epithelium of the hamster cauda epididymidis and found that radioactive small molecular weight compounds equilibrated with epididymal luminal fluid within a short time; larger molecular weight compounds entered the lumen more slowly. Cooper \& Waites (1979) using an in-vivo luminal perfusion technique demonstrated that the epithelium of the rat cauda epididymidis was also relatively impermeable to high molecular weight compounds. Neither of these studies included observations on the caput region of the epididymis. Since the epithelial morphology changes along the length of the rat epididymis (Reid \& Cleland, 1957), it cannot be assumed that the permeability properties of the cauda epithelium are similar to those of the rest of the epididymal epithelium. Similarly, it cannot be assumed that the permeability properties of the testicular and epididymal epithelia are identical for each species. This latter point has been clearly demonstrated by Howards et al. (1976) who showed that hamster seminiferous tubules were not freely permeable to $\left[{ }^{14} \mathrm{C}\right]$ urea; which is in direct contrast to results of studies on rams and rats (see Setchell \& Waites, 1975). This study was therefore undertaken to determine whether the permeability properties of the epithelium of the rat caput epididymidis are similar to those of the cauda epididymidis. Study of the rat caput epididymidis is important because several organic compounds are secreted into luminal fluid in this area (Hinton, Snoswell \& Setchell, 1979b; Hinton \& Setchell, 1980b; see Hinton, 1980). 


\section{Materials and Methods}

Rats

Adult male Sprague-Dawley rats (372-547 g; Hilltop, Philadelphia, U.S.A.) were housed in the University Vivarium under a $12 \mathrm{~h}$ light/12 h dark cycle (lights on 06:00 h) and had free access to food and water.

\section{Isotopes}

The following isotopes were purchased from New England Nuclear (Boston, Massachusetts, U.S.A.) or Amersham (Arlington Heights, Illinois, U.S.A.): ${ }^{3} \mathrm{H}_{2} \mathrm{O}$ (sp. act. $1 \mathrm{mCi} / \mathrm{g}$ ); $\left[{ }^{14} \mathrm{C}\right]$ urea (sp. act. $59 \mathrm{mCi} / \mathrm{mmol}$ ); methoxy $\left[{ }^{3} \mathrm{H}\right]$ inulin (sp. act. $488.4 \mathrm{mCi} / \mathrm{g}$ ); $\left[1,2-{ }^{3} \mathrm{H}\right]$ polyethylene glycol (sp. act. $2 \mathrm{mCi} / \mathrm{g}$ ); and ${ }^{125} \mathrm{I}$-labelled bovine serum albumin (sp. act. $0.6 \mathrm{mCi} / \mathrm{g}$.).

\section{Surgery and micropuncture}

Rats were anaesthetized with an intraperitoneal injection of urethane (ethyl carbamate, 1.2 $\mathrm{mg} / \mathrm{g}$ ), and cannulae (PE 50) were inserted into the jugular vein and the carotid artery; the renal blood vessels were ligated close to each kidney with a $4 / 0$ suture to prevent the excretion of radioactive material. $\mathrm{A}$ testis and epididymis were exposed through a scrotal incision and prepared for micropuncture as previously described (Hinton, Dott \& Setchell, 1979a). Samples of luminal contents were collected from the middle of the caput epididymidis (Site 2, see Hinton et al., 1979a) at $34-35^{\circ} \mathrm{C}$ (Brooks, 1973). The luminal contents were centrifuged and aliquots of the supernatant were transferred into Bio-vials (Beckman, Somerset, New Jersey, U.S.A.) containing $3 \mathrm{ml}$ scintillation fluid ("Baker Analysed" Reagent; LSC Cocktail 1:2 Triton X100/toluene-based: J. T. Baker, Phillipsburg, New Jersey, U.S.A.). Blood plasma was treated in a similar manner. For experiments that involved ${ }^{125} \mathrm{I}$-labelled bovine serum albumin, aliquots of supernatant were transferred into plastic test-tubes $(12 \times 75 \mathrm{~mm}$; Fisher Scientific Co., Pittsburg, Pennsylvania, U.S.A.) containing $1 \mathrm{ml}$ distilled water and counted for radioactivity (Beckman Biogamma 11).

\section{Injection and collection procedure}

Each isotope (see above) was prepared as $1 \mathrm{mCi}$ radioactivity in $1 \mathrm{ml}$ saline $(9 \mathrm{~g} \mathrm{NaCl} / \mathrm{l})$ and injected into the jugular vein of each animal over a period of 2-3 min. Blood samples were collected from the carotid cannula at various times thereafter and epididymal luminal contents were collected by micropuncture over a period of 10-20 min. The blood sample was taken at the mid-point of luminal collection.

In one series of experiments, 3 rats were anaesthetized with pentobarbitone sodium (Nembutal; $50 \mathrm{mg} / \mathrm{kg}$ ), the renal blood vessels were ligated and $1 \mathrm{mCi}\left[{ }^{3} \mathrm{H}\right]$ inulin was injected (in $1 \mathrm{ml}$ ) into the jugular vein through a 30-gauge needle. The incisions were sutured and the animals allowed to recover. Micropuncture and blood plasma samples were collected $18 \mathrm{~h}$ later as described above.

\section{Calculations}

For each collection time, the results were expressed as c.p.m. in luminal fluid/c.p.m. in blood plasma $\times 100=\%$ plasma isotope appearing in luminal fluid (see Howards et al., 1976). 


\section{Results}

Table 1 shows the results of the transfer of ${ }^{3} \mathrm{H}_{2} \mathrm{O}$ and $\left[{ }^{14} \mathrm{C}\right]$ urea from blood plasma to the epididymal lumen. The compounds reached equilibration within $20 \mathrm{~min}\left({ }^{3} \mathrm{H}_{2} \mathrm{O}\right)$ and $2 \mathrm{~h}$ ( $\left[{ }^{14} \mathrm{C}\right.$ lurea).

Table 1. The amounts (as \% of the plasma isotope concentrations) of different substances appearing in the luminal fluid of the caput epididymidis of the rat at various times after intravenous injection

\begin{tabular}{|c|c|c|c|c|c|}
\hline $\begin{array}{l}\text { Time after } \\
\text { injection } \\
\text { (min) }\end{array}$ & ${ }^{3} \mathrm{H}_{2} \mathrm{O}$ & {$\left[{ }^{14} \mathrm{C}\right]$ Urea } & {$\left[{ }^{3} \mathrm{H}\right]$ Inulin } & $\begin{array}{c}{\left[{ }^{3} \mathrm{H}\right] \text { Polyethylene }} \\
\text { glycol }\end{array}$ & $\begin{array}{l}{ }^{125} \text { I-labelled } \\
\text { BSA }\end{array}$ \\
\hline 10 & $82 \cdot 1 \pm 8 \cdot 6(4)$ & - & - & - & - \\
\hline 20 & $96 \cdot 3 \pm 3 \cdot 7(7)$ & $71 \cdot 3 \pm 4 \cdot 2(5)$ & $1.5 \pm 0.5(8)$ & - & - \\
\hline 40 & $100 \cdot 8 \pm 5.4(7)$ & $86.9 \pm 1.8(5)$ & $2 \cdot 1 \pm 0.3(8)$ & - & - \\
\hline 60 & $106 \cdot 2 \pm 3 \cdot 6(7)$ & $88 \cdot 3 \pm 3 \cdot 3(5)$ & $2.9 \pm 0.4(9)$ & $1 \cdot 0 \pm 0 \cdot 2(5)$ & $1 \cdot 1 \pm 0.3(4)$ \\
\hline 90 & $105.4 \pm 1.9(7)$ & - & $3.2 \pm 0.7(6)$ & - & - \\
\hline 120 & $103.6 \pm 1.4(7)$ & $97.2 \pm 2 \cdot 2(5)$ & $2 \cdot 6 \pm 0.3(5)$ & $1.4 \pm 0.2(5)$ & $2.3 \pm 0.2(4)$ \\
\hline 180 & - & - & $4.3 \pm 0.8(4)$ & $3.8 \pm 0.5(5)$ & $4.0 \pm 0.6(4)$ \\
\hline 1080 & - & - & $6.8 \pm 0.4(3)$ & - & - \\
\hline
\end{tabular}

Values are mean \pm s.e.m. for the no. of animals in parentheses.

The compounds $\left[{ }^{3} \mathrm{H}\right]$ polyethylene glycol, $\left[{ }^{3} \mathrm{H}\right]$ inulin and ${ }^{125} \mathrm{I}$-labelled bovine serum albumin in the lumen reached less than $5 \%$ of blood plasma over the 3 -h period; $\left[{ }^{3} \mathrm{H}\right]$ inulin transfer was $<7 \%$ even at $18 \mathrm{~h}$ after injection.

\section{Discussion}

This study has shown that a permeability barrier exists in the rat caput epididymidis. In the present study, ${ }^{3} \mathrm{H}_{2} \mathrm{O}$ equilibrated more quickly between blood plasma and rat caput luminal fluid than it did between the blood and cauda fluid of the hamster as reported by Howards et al. (1976). This could be due to differences in blood flow between the caput and cauda regions (see Setchell, Waites \& Till, 1964), species differences or subtle differences in the techniques. Whatever the cause, this study and earlier studies by Howards et al. (1976) and Cooper \& Waites (1979) demonstrate that the epididymal epithelium is freely permeable to compounds of low molecular weight. The larger molecular weight compounds used in this study, $\left[{ }^{3} \mathrm{H}\right]$ polyethylene glycol (mol. wt 4000), $\left[{ }^{3} \mathrm{H}\right]$ inulin (mol. wt 5500-6000) and ${ }^{125} \mathrm{I}$-labelled bovine serum albumin (assumed mol. wt 60000 ) did not penetrate the caput epithelium readily. Each of these compounds in the lumen reached less than $5 \%$ of blood plasma by $3 \mathrm{~h}$ after injection and even after $18 \mathrm{~h},\left[{ }^{3} \mathrm{H}\right]$ inulin remained less than $7 \%$.

The permeability barrier is probably situated at the tight junctions between the epithelial cells of the epididymis (Suzuki \& Nagano, 1978a, b) and the compounds used in this study probably transfer across this epithelium by simple diffusion. The tight junctions in the caput epididymidis of the rat and mouse are numerous and well developed (Suzuki \& Nagano, 1978a, b) but the degree of impermeability of the epithelium is not necessarily correlated with the number of tight junctions (Martinez-Palomo \& Erlig, 1975). We assume that in this tissue, as in the testes (see Setchell, 1978), the epithelia of the blood vessels do not significantly interfere in the transfer of the compounds across the epithelium of the caput epididymidis.

It is possible that the radioactive compounds may have entered the lumen of the caput epididymidis via the efferent ducts or rete testis. The former site must be considered since there is morphological evidence to suggest that this epithelium is quite permeable (Suzuki \& Nagano, 1978a). However, in separate experiments involving ligation of the efferent ducts close to the 
testis or close to the epididymis, the entry of radioactive inulin into the caput fluid was not significantly different from that of the normal intact animal (B. T. Hinton \& S. S. Howards, unpublished observations). Also, since the transit time of spermatozoa, and presumably fluid from rete testis, to caput and cauda epididymidis is of the order of days (see Hamilton, 1972) and the experiments performed in this study were of the order of minutes, it would seem unlikely that the radioactivity detected in the lumen of the caput epididymidis would originate from the rete testis or efferent ducts. The rete testis of the rat has been shown to be relatively impermeable to large molecular weight compounds (see Setchell \& Waites, 1975).

Because of the restricted penetration of many substances across the epididymal epithelium, this tissue must therefore utilize various carrier mechanisms to transport required substances across its epithelia to provide a favourable microenvironment for sperm maturation. These substances may also be required for normal epididymal function. Several carrier mechanisms seem to exist on the membranes of the epididymal cells. The active transport of carnitine in the rat caput and corpus epididymidis is well documented (Brooks, Hamilton \& Mallek, 1973; Johansen \& Bøhmer, 1979; Hinton \& Setchell, 1980a) and the entry of glucose into the epididymis has been shown to be via a facilitated diffusion mechanism (Brooks, 1979; Cooper \& Waites, 1979). The epididymis can also control the movement of inorganic ions across its epithelium (Levine \& Marsh, 1971; Wong, Au \& Ngai, 1978).

Further understanding of the basic properties of the epididymal epithelium will provide information on the maintenance of the specialized microenvironment which seems to be important for sperm maturation.

This investigation received the financial support of the Rockefeller Foundation: B.T.H. is a Rockefeller Foundation Fellow. S.S.H. is the recipient of a National Institutes of Health Career Development Award No. 10K04-HD-108-01.

\section{References}

Brooks, D.E. (1973) Epididymal and testicular temperature in the unrestrained conscious rat. $J$. Reprod. Fert. 35, 157-160.

Brooks, D.E. (1979) Carbohydrate metabolism in the rat epididymis: evidence that glucose is taken up by tissue slices and isolated cells by a process of facilitated diffusion. Biol. Reprod. 21, 19-26.

Brooks, D.E., Hamilton, D.W. \& Mallek, A.H. (1973) The uptake of $\mathrm{L}-\left[\right.$ methyl- $\left.{ }^{3} \mathrm{H}\right]$ carnitine by the rat epididymis. Biochem. Biophys. Res. Commun. 52, 1354-1360.

Cooper, T.G. \& Waites, G.M.H. (1979) Investigation by luminal perfusion of the transfer of compounds into the epididymis of the anaesthetized rat. J. Reprod. Fert. 56, 159-164.

Dym, M. \& Fawcett, D.W. (1970) The blood-testis barrier in the rat and the physiological compartmentation of the seminiferous epithelium. Biol. Reprod. 3, 308-326.

Fawcett, D.W., Leak, L.B. \& Heidger, P.M. (1970) Electron microscopic observations on the structural components of the blood-testis barrier. J. Reprod. Fert., Suppl. 10, 105-122.

Hamilton, D.W. (1972) Mammalian epididymis. In Reproductive Biology, pp. 268-337. Eds H. Balin \& S. Glasser. Excerpta Medica, Amsterdam.

Hinton, B.T. (1980) The epididymal microenvironment: a site of attack for a male contraceptive? Invest. Urol. 18, 1-10.
Hinton, B.T. \& Setchell, B.P. (1980a) Concentration and uptake of carnitine in the rat epididymis. A micropuncture study. In Carnitine Biosynthesis, Metabolism and Function, pp. 237-250. Eds R. A. Frankel \& J. D. McGarry. Academic Press, New York.

Hinton, B.T. \& Setchell, B.P. (1980b) The concentration of glycerophosphocholine, phosphocholine and free inorganic phosphate in the luminal fluid of the rat testis and epididymis. J. Reprod. Fert. 58, 401-406.

Hinton, B.T., Dott, H.M. \& Setchell, B.P. (1979a) Measurement of the motility of rat spermatozoa collected by micropuncture from the testis and from different regions along the epididymis. J. Reprod. Fert. 55, 167-172.

Hinton, B.T., Snoswell, A.M. \& Setchell, B.P. (1979b) The concentration of carnitine in the luminal fluid of the testis and epididymis of the rat and some other mammals. J. Reprod. Fert. 56, 105-111.

Howards, S.S., Jessee, S.H. \& Johnson, A.L. (1976) Micropuncture studies of the blood-seminiferous tubule barrier. Biol. Reprod. 14, 264-269.

Johansen, L. \& Bøhmer, T. (1979) Uptake of ${ }^{3} \mathrm{H}$ L-carnitine by isolated rat epididymal tubules. Arch. Androl. 2, 117-121.

Levine, N. \& Marsh, D.J. (1971) Micropuncture studies of the electrochemical aspects of fluid and electrolyte transport in individual seminiferous tubules, the epididymis and the vas deferens in rats. $J$. Physiol., Lond. 213, 557-570. 
Martinez-Palomo, A. \& Erlig, D. (1975) Structure of the tight junctions in epithelia with different permeability. Proc. natn. Acad. Sci. U.S.A. 72, 4487-4491.

Reid, B.L. \& Cleland, K.W. (1957) Structure and function of the epididymis. 1. The histology of the rat epididymis. Aust. J. Zool. 5, 223-246.

Setchell, B.P. (1978) The Mammalian Testis. Elek Books, London.

Setchell, B.P. (1980) The functional significance of the blood-testis barrier. J. Androl. 1, 3-10.

Setchell, B.P. \& Waites, G.M.H. (1975) The blood-testis barrier. In Handbook of Physiology Section 7: Endocrinology, Vol. 5: Male Reproductive System, pp. 143-172. Eds D. W. Hamilton \& R. O. Greep. Am. Physiol. Soc. Washington, D.C.
Setchell, B.P., Waites, G.M.H. \& Till, A.R. (1964) Variations in flow of blood within the epididymis and testis of the sheep and rat. Nature, Lond. 203, 317-318.

Suzuki, F. \& Nagano, T. (1978a) Regional differentiation of cell junctions in the excurrent duct epithelium of the rat testis as revealed by freeze-fracture. Anat. Rec. 191, 503-520.

Suzuki, F. \& Nagano, T. (1978b) Development of tight junctions in the caput epididymal epithelium of the mouse. Devl Biol. 63, 321-334.

Wong, P.Y.D., Au, C.L. \& Ngai, H.K. (1978) Electrolyte and water transport in rat epididymis; its possible role in sperm maturation. Int. J. Androl., Suppl. 2, 608-628.

Received 9 October 1980 